Incurable and Intolerable 



\section{Incurable and Intolerable}

Chronic Disease and Slow Death in Nineteenth-Century France

JASON SZABO

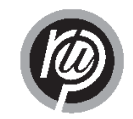

RUTGERS UNIVERSITY PRESS 


\section{LIBRARY OF CONGRESS CATALOGING-IN-PUBLICATION DATA}

Szabo, Jason, I965-

Incurable and intolerable : chronic disease and slow death in nineteenthcentury France / Jason Szabo.

p. ; cm.

Includes bibliographical references and index.

ISBN 978-O-8I35-4545-5 (hardcover : alk. paper)

I. Chronic diseases-France-History-I9th century. 2. Palliative treatmentFrance-History-Igth century. I. Title.

[DNLM: I. Chronic Disease-psychology-France. 2. History of MedicineFrance. 3. History, I9th Century-France. WZ 70 GF7 S996i 20o9]

RA644.8.F8S93 2009

6I6'.044-dc22

2008035431

A British Cataloging-in-Publication record for this book is available from the British Library.

Copyright (c) 2009 Jason Szabo

All rights reserved

No part of this book may be reproduced or utilized in any form or by any means, electronic or mechanical, or by any information storage and retrieval system, without written permission from the publisher. Please contact Rutgers University Press, Ioo Joyce Kilmer Avenue, Piscataway, NJ 08854-8099. The only exception to this prohibition is "fair use" as defined by U.S. copyright law.

Visit our Web site: http://rutgerspress.rutgers.edu

Manufactured in the United States of America 
To the memory of my parents 
